ACTA IURIS STETINENSIS 2 (14)

DOI: 10.18276/ais.2016.14-09

\title{
Szymon Słotwiński
}

\section{GLOSA DO WYROKU SĄDU NAJWYŻSZEGO \\ Z 27 MAJA 2015 ROKU, SYGN. II CSK 502/14 \\ (UPRAWNIENIE DO KORZYSTANIA Z RZECZY \\ I POBIERNIA Z NIEJ POŻYTKÓW) ${ }^{1}$}

\begin{abstract}
Streszczenie
W glosowanym wyroku poruszono problem zbywania uprawnienia do korzystania z rzeczy i pobierania z niej pożytków. Sąd Najwyższy oparł swoje rozstrzygnięcie na dwóch założeniach. Po pierwsze, uprawnienie do korzystania z rzeczy i pobierania z niej pożytków naturalnych jest samoistnym przedmiotem obrotu prawnego (por. art. 252 i 693 § 1 k.c.) i może na podstawie umowy przysługiwać innej osobie niż właścicielowi, w szczególności użytkownikowi (a także użytkownikowi wieczystemu) lub dzierżawcy. Po drugie, może też być wiele osób, które są związane odpowiednimi stosunkami wynikającymi z umowy, z których ostatnia jest uprawniona do pobierania pożytków naturalnych (np. właściciel nieruchomości ustanawia użytkowanie na rzecz określonej osoby, która tę nieruchomość wydzierżawia innej osobie, a ta oddaje ją w poddzierżawę). O nabyciu własności tych pożytków decyduje przy tym w zasadzie istnienie odpowiedniego uprawnienia, a nie faktyczne posiadanie rzeczy macierzystej w chwili odłączenia, chyba że rzecz ta znajduje się w posiadaniu innej niż uprawniony osoby w dobrej wierze.
\end{abstract}

Słowa kluczowe: prawo cywilne, korzystanie z rzeczy, pobieranie pożytków

Zagadnienia poruszane w komentowanym orzeczeniu Sądu Najwyższego dotyczą kwestii, które z jednej strony wydają się bardzo oczywiste - o czym

* Szymon Słotwiński, Uniwersytet Szczeciński; adres e-mail: szymon.slotwinski@wpiaus.pl.

1 LEX nr 1764803. 
może świadczyć dosyć zwięzłe uzasadnienie wyroku - zaś z drugiej strony mają w sobie niebagatelny potencjał teoretyczny. Problematyka prawna pożytków i źródeł uprawnienia do ich pobierania ma przecież przełożenie na obrót gospodarczy, nie tylko przez wzgląd na znaczenie tego zagadnienia dla treści prawa własności jako jednego z atrybutów uprawnień właściciela, ale także przez wywieranie wpływu na wybór charakteru (obligacyjny lub prawnorzeczowy) nawiązywanego pomiędzy kontrahentami stosunku prawnego. Niekiedy zaś sama możliwość pobierania pożytków ma znaczenie decydujące przy przesądzaniu, jaki rodzaj umowy został zawarty pomiędzy stronami ${ }^{2}$ oraz czy należy on do typu umów nazwanych lub nienazwanych ${ }^{3}$.

Zakres rozważań Sadu Najwyższego został wyznaczony następującym stanem faktycznym. W 2007 roku powódka jako zleceniobiorca zawarła z dzierżawcą gruntu umowę o świadczenie usług rolniczych. Do obowiązków powódki należało również zbieranie plonów z pól. W 2012 roku, wskutek prowadzonego przeciwko dzierżawcy postępowania egzekucyjnego, komornik zajął zasiewy, następnie zebrał plony, które ostatecznie sprzedał za ponad 120 tys. zł. Powódka wystąpiła o zwolnienie wskazanej kwoty spod egzekucji, powołując się na swoje uprawnienie do pobierania pożytków i przysługujące jej prawo własności tych pożytków. Powódka swoje prawa wywodziła z zawartej w 2007 roku umowy oraz przepisów prawa (art. 55 k.c. oraz 190 k.c.). Sąd Apelacyjny nie podzielił poglądu powódki i powództwo oddalił. Na podstawie naruszenia przez Sąd Apelacyjny art. $65 \S 2$ k.c., art. 55 k.c. w zw. z art. 190 k.c. oraz art. $155 \S 2$ k.c. powódka złożyła skargę kasacyjną. Po rozpoznaniu wniesionej skargi kasacyjnej Sąd Najwyższy rozstrzygnął, że: ,uprawnienie do korzystania z rzeczy i pobierania z niej pożytków naturalnych jest samoistnym przedmiotem obrotu prawnego (por. art. 252 i $693 \S 1$ k.c.) i może na podstawie umowy przysługiwać innej osobie niż właściciel, w szczególności użytkownikowi (a także użytkownikowi wieczystemu) lub dzierżawcy. Może też istnieć cały szereg osób, które są związane odpowiednimi stosunkami wynikającymi z umowy i z których ostatnia w tym szeregu jest uprawniona do pobierania pożytków naturalnych (np. właściciel nieruchomości ustanawia użytkowanie na rzecz określonej osoby, która

\footnotetext{
2 Np. najem a dzierżawa zob. J. Panowicz-Lipska, w: System Prawa Prywatnego. Prawo zobowiązań-część szczegółowa, t. 8, red. J. Panowicz-Lipska, Warszawa 2011, s. 18.

3 Zob. Wyrok Sądu Najwyższego z 5.10.2012 r., sygn. IV CSK 244/12, Legalis z glosami: Ł. Wyszomirskiego, Orzecznictwo Sądów Polskich 2013, nr 10, s. 686; Z. Kuniewicza, S. Słotwińskiego, „Przegląd Prawa Rolnego” 2013, nr 2, s. 190.
} 
tę nieruchomość wydzierżawia innej osobie, a ta oddaje ją w poddzierżawę). O nabyciu własności tych pożytków decyduje przy tym w zasadzie stan prawny - istnienie odpowiedniego uprawnienia, a nie faktyczne posiadanie rzeczy macierzystej w chwili odłączenia, chyba że rzecz ta znajduje się w posiadaniu innej niż uprawniony osoby w dobrej wierze".

Stanowisko zajęte przez Sąd Najwyższy zasługuje w pełni na aprobatę, zatem celem niniejszej glosy jest wzmocnienie argumentacji zawartej w uzasadnieniu wyroku oraz rozwinięcie niektórych wątków tego uzasadnienia.

W uzasadnieniu wyroku postawiono interesującą tezę, że uprawnienie do korzystania z rzeczy i pobierania pożytków jest samoistnym przedmiotem obrotu prawnego i może przysługiwać innemu, niż właściciel, podmiotowi. Wśród przykładów stosunków prawnych umożliwiających przekazywanie tego uprawnienia posłużono się jedynie znanymi z Kodeksu cywilnego konstrukcjami prawnorzeczowymi i obligacyjnymi, które do tego uprawnienia się wprost odnoszą. Pojawia się w tym momencie wątpliwość, czy na pewno omawiane uprawnienie jest na tyle niezależne od innych relacji prawnych, aby uznać je za samoistny przedmiot obrotu. Rzeczywiście jest tak, że przepisy części ogólnej Kodeksu cywilnego odnoszące się do zagadnienia pożytków - pomimo odwoływania się do terminu „uprawnionego do pobierania pożytków” (np. art. 55 k.c.) - nie wskazują źródła tego uprawnienia, koncentrując się głównie na związku czasowym, w którym odłączone pożytki przypadają właśnie uprawnionemu, a nie podmiotowi, który to uprawnienie mu przekazał. W doktrynie zgodnie przyjmuje się, że jedynym kryterium przesądzającym o tym uprawnieniu są właściwe przepisy regulujące sposób korzystania z rzeczy zarówno na płaszczyźnie praw o charakterze bezwzględnym, jak i względnym ${ }^{4}$. Analiza przepisów Kodeksu cywilnego dowodzi różnorodności stosunków prawnych, których specyfika wyraża się właśnie w możliwości pobierania pożytków. Ius fruendi jest w zasadzie nieodzownym elementem prawa własności rzeczy (art. 140 k.c.), użytkowania wieczystego (art. 233 k.c.), użytkowania (art. 252 k.c.), podnajmu (art. 668 k.c.), dzierżawy (art. 693 oraz 698 k.c.) oraz leasingu (art. $709^{1}$ k.c.). Samo samoistne i zależne po-

4 E. Gniewek, w: System Prawa Prywatnego, Prawo rzeczowe, t. 3, Warszawa 2013, s. 651; Ł. Żelechowski, w: Kodeks cywilny. Komentarz, red. K. Osajda, Warszawa 2016, komentarz do art. 55 k.c., nb. 8, Legalis (15.05.2016); E. Gniewek, w: Kodeks cywilny. Komentarz, red. E. Gniewek, P. Machnikowski, Warszawa 2016, komentarz do art. 55 k.c., nb. 1, Legalis (15.05.2016); M. Pazdan, w: Kodeks cywilny, t. I. Komentarz. Art. 1-44910, red. K. Pietrzykowski, Warszawa 2015, komentarz do art. 55 k.c., nb. 1, Legalis (15.05.2016). 
siadanie w dobrej wierze stanowi także przykład legalnego tytułu do pobierania pożytków z prawem zachowania ich dla siebie, co dowodzi, że niekiedy to nieograniczone prawo rzeczowe lub stosunek obligacyjny, ale okoliczności faktyczne przesądzają o przysługiwaniu oraz zgodnym z prawem wykonywaniu tego uprawnienia (art. $224 \S 1$ k.c. wraz z art. 230 k.c.) $)^{5}$.

Wydaje się, że wydźwięk komentowanego orzeczenia, który wprost wpisuje się w poglądy doktryny prawa cywilnego jest taki, że z samoistnością uprawnienia do pobierania pożytków nie idzie w parze swoboda doboru instrumentów przekazujących to uprawnienie ponad wskazane wyżej relacje prawne. Przesądza o tym też zastosowany w uzasadnieniu wyroku wyraźne odróżnienie czynności prawnych dotyczących pożytków, na te których przedmiotem jest uprawnienie do pobierania pożytków, od tych, których przedmiotem jest przeniesienie własności pożytków jako rzeczy przyszłych. W tym sensie o zbywalności ius fruendi nie wnioskuje się z jego charakteru ${ }^{6}$, ale z konstrukcji prawnych, które pozwalają ten skutek osiągnąć. Przedstawiony jednak sposób interpretacji zapadłego rozstrzygnięcia nie wydaje się prawidłowy, zwłaszcza w zakresie prowadzącym ostatecznie do uznania, że przenoszenie uprawnienia do pobierania pożytków na inne podmioty może się odbywać wyłącznie na podstawie wyrażonych wprost w Kodeksie cywilnym umów. W ten sposób ostatecznie doprowadzi się do zaakceptowania - znanej z prawa rzeczowego - zasady numerus clausus umów, składających się na obrót uprawnieniem do pobierania pożytków. Takie stanowisko nie może być uprawnione z trzech powodów.

Po pierwsze, nie ma tutaj wystarczających argumentów przemawiających za tak restrykcyjnym podejściem. Przede wszystkim dlatego, że samo przekazanie ius fruendi jest skuteczne wyłącznie w relacjach pomiędzy stronami takiego stosunku, wskazując jedynie legitymacje do ich pobrania. Nie zaliczy się tego uprawnienia jako skutecznego erga omnes, jeśli zostało przekazane przez wła-

5 J.S. Piątowski, w: System prawa cywilnego. Prawo własności i inne prawa rzeczowe, t. II, red. J. Ignatowicz, Ossolineum 1977, s. 375; M. Bednarek, Mienie. Komentarz do art. 44-55 Kodeksu cywilnego, Kraków 1997, s. 174.

6 Jako prawo zbywalne. Jednak T. Sokołowski, w: Kodeks cywilny. Tom I. Komentarz do art. 1-44911, red. M. Gutowski, Warszawa 2016, komentarz do art. 55 k.c., nb. 3, Legalis (15.05.2016) stwierdza, że „Uprawnienie do pobierania pożytków naturalnych, ujmowane w sposób wyodrębniony jest prawem niezbywalnym (aczkolwiek można je obciążyć). (...) Nie można także zawrzeć umowy nienazwanej obligacyjnej, której treścią byłoby tylko prawo do pobierania tych pożytków, bez związku z innymi elementami określających zakres wzajemnego świadczenia, co jest typowe dla dzierżawy". 
ściciela innemu podmiotowi. A właśnie taka skuteczność praw bezwzględnych przesądza o ich zamkniętym katalogu. Należy zaznaczyć, że pożytki naturalne do chwili odłączenia stanowią część składową rzeczy, więc w przypadku jakichkolwiek naruszeń ze strony osób trzecich, to właścicielowi tej rzeczy służy najdalej idąca ochrona, zaś w przypadku uprawnionego do pobierania pożytków wszystko zależy od rodzaju stosunku prawnego, z którego owo uprawnienie wynika. Nie jest również wykluczone, że na podstawie przepisów szczególnych uprawnionemu, co do zasady, służy taka sama ochrona jak właścicielowi (art. 690 k.c. lub 251 k.c.). Inaczej omawiana kwestia przedstawia się po odłączeniu pożytków od rzeczy. Z tego względu samo uprawnienie do pobierania pożytków nie przesądza jeszcze o skutkach prawnorzeczowych, ponieważ ex lege powstaną one dopiero z chwilą odłączenia pożytków od rzeczy (art. 190 k.c.). Uprawniony wówczas staje się zarazem właścicielem, a charakter prawny źródła tego uprawnienia (obligacyjne lub prawnorzeczowe) przestaje mieć znaczenie. W tym sensie jednak bardzo istotne jest komu przysługuje stosowna legitymacja do odłączenia części składowej rzeczy i uczynienia z niej przedmiotu odrębnej własności.

Po drugie, operowanie przez przepisy prawa pojęciem „uprawnionego do pobierania pożytków" bez łączenia zakresu znaczeniowego tego pojęcia z potencjalnymi ograniczeniami przedmiotowymi - zwłaszcza co do źródła tego uprawnienia - lege non distinguente dowodzi, że ten katalog ma pozostać otwarty.

I wreszcie po trzecie, obrót uprawnieniem do pobierania pożytków przyjmuje postać ograniczania swojego uprawnienia na rzecz innego podmiotu, który w określonym okresie będzie je wykonywać. Nie można zapomnieć, że głównym źródłem dla ius fruendi jest właśnie prawo własności i ta więź nie ustaje przez nawiązywanie kolejnych relacji umownych legitymujących kolejne podmioty do pobierania pożytków z wyłączeniem poprzedników. Wystarczy przywołać przykład użyty w komentowanym wyroku, jasno wskazujący potencjalną możliwość wielowarstwowości nawiązywanych relacji prawnych jedynie w zakresie możliwości pobierania pożytków.

Wskazane argumenty mają doniosłe znaczenie dla stosunków umownych skutecznych inter partes. Gdy przełoży się wskazane założenia na stosunki obligacyjne okaże się, że postulat otwartości źródeł tytułów dla uprawienia do pobierania pożytków jest wręcz umacniany. Głównie dzięki treści art. $353^{1}$ k.c. i wynikającej z niego kompetencji dla podmiotów prawa cywilnego do kształtowania nowych relacji umownych. Wydaje się, że właściwość (natura) stosunku, 
ustawa oraz zasady współżycia społecznego nie wykluczają możliwości powołania nienazwanego stosunku umownego, który również będzie traktowany jak źródło uprawnienia do pobierania pożytków, a nie zostanie zaklasyfikowany jako jeden z wskazanych wcześniej stosunków prawnych uregulowanych przepisami Kodeksu cywilnego lub w ostateczności jako umowa sprzedaży rzeczy przyszłej. Treść tak utworzonego stosunku zobowiązaniowego nie wypaczy bowiem ani właściwości (natury) stosunków obligacyjnych, ponieważ niekiedy możliwość pobierania pożytków stanowi element przedmiotowo istotny umów pozwalających na korzystanie z rzeczy cudzej, ani w zasadzie nie naruszy ustawy, chyba że strony będą zmierzać do naruszenia fundamentalnych zasad prawa rzeczowego. W ocenianym przez Sąd Najwyższy stanie faktycznym zawarto umowę, która wyręczała uprawnionego do pobierania pożytków z możliwości odłączania ich od rzeczy oraz zbierania już odłączonych, a tym samym zobowiązywała jedną ze stron do dokonywania właśnie tych czynności faktycznych, które wywołują ex lege nabycie własności pożytków przez uprawnionego. $Z$ tego powodu zapadłe orzeczenie w pełnym zakresie należy zaaprobować, jednak wskazaną umowę bez wątpienia należy zakwalifikować do umów o świadczenie usług, o których traktuje art. 750 k.c. W przypadku ułożenia treści w taki sposób, aby umowę móc uznać za odpłatną, nic nie stoi na przeszkodzie, by należne stronie przyjmującej wynagrodzenie zostało ustalone jako możliwość pobrania odpowiedniej części pożytków z rzeczy ze skutkami określonymi w art. 55 k.c. w zw. z 190 k.c. Aczkolwiek odróżnić należy ten układ stosunków od sytuacji, gdy wynagrodzenie ustalone będzie w części już pobranych pożytków, ponieważ po stronie przyjmującego nie powstanie wówczas jakiekolwiek uprawnienie do pobrania pożytków, o którym tutaj mowa.

Na tej podstawie jest możliwe tworzenie stosunków obligacyjnych z uprawnieniem do pobierania pożytków ponad te nazwane i wskazane w rozstrzygnięciu Sądu Najwyższego, poprzez zawieranie umów nienazwanych czyniących uprawnienie do pobierania pożytków nie tylko samoistnym przedmiotem obrotu, ale także swobodnym co do wyboru sposobu jego wykonywania. 


\section{GLOSS TO THE JUDGMENT OF THE SUPREME COURT DATED 27 MAY 2015, REF . II CSK 502/14}

The main problem of judgment of the Supreme Court dated 27 May 2015 is disposing of the right to use things and usufruct. The Supreme Court based its decision on two assumptions. Firstly, the right to the use of things and natural usufruct is autonomous traded law (see. Art. 252 and $693 \S 1$ of the Civil Code), and may contractually entitled to a person other than the owner, in particular the user (and perpetual user) or tenant. There can also be a whole range of people who are bound by appropriate relations under the contract and the last one in the series is entitled to receive the natural usufruct (eg. The property owner sets use for a particular person, that this property leased to another person, and this gives it in sublet). The acquisition of ownership of these usufruct determined by the essentially legal status - the existence of a privilege, not an actual possession of the main things at the time of disconnection, unless this thing is in the possession of non-authorized persons in good faith.

Keywords: civil law, the use of things, usufruct 